\title{
Improving Children's Love to Local Culture Through Culture-Themed "APE” Puzzle Product
}

\author{
Ponimin \\ Art and Design Department, Faculty of Letters \\ Universitas Negeri Malang \\ Malang, Indonesia \\ ponimin.fs@um.ac.id
}

\begin{abstract}
Educational Game Tool (APE) that is used for early childhood in pre-school institution - Kindergarten of Batu City, East Java Province has less local culture theme. It made the early-age children aren't familiar with their own culture. They need local culture-based APE product as a media to boost children's interest in the local culture. This research has proved that educational tool plays an important role in the educational process. The research method used a creative approach. This approach intended to produce a concept of APE product design development. This research was started by formulating the product design development, continued with the product design shape exploration through the various APE puzzle pre-design image with various cultural themes. The alternative image results were selected and embodied in the product prototype. Before it was tested to Kindergarten students of Batu City, the development prototype is validated to APE product design expert and early childhood learning media expert. Validation and field test results of APE product design development showed that the product design development is appropriate to be applied to the early-age children. The product design includes a puzzle with Wayang Purwo theme, Bali dance, Reog of Ponorogo dance and Leathered horse.
\end{abstract}

Keywords—educational game tool, local culture based.

\section{INTRODUCTION}

Children's psychosocial development less well developed if they are far from their environment. It includes an introduction to add knowledge to the cultural environment since the early age. Introduction to the culture is needed to boost their love to local culture, it can be started earlier through a culture-themed educational game tool. The game will improve their right and left brain in recording, absorbing, saving, producing, and reconstructing information from the game effect [3].

Playing activity with their media will influence the children's development and growth. A research conducted by The Reiner Foundation in 1999 mentioned that playing activity is heavily influenced by the tool which supports their emotion. It is done by giving Educational Game Tool (APE) with local culture-themed game. The tool will give direct experience by using the children's senses (sight, hearing, taste, touch, smell), through interaction touching, smiling, singing, listening carefully, responding children's words, bringing a conversation with a soft voice and giving safety. The touch is really helpful in stimulating the brain and producing the hormone needed for development. Orawiwatnakul [4] concluded that game can improve students' knowledge, and their learning motivation. In his research, he used crosswords puzzle and successfully improved the Elementary School students' vocabulary knowledge. Malik and Agarwal [1] concludeed that Multimedia tool empowers the educational process by increasing the interaction between children and students. The research conducted by Melero and Hernandez-Leo [2] also showed that puzzle-based game is a good particular strategy to foster students' problem-solving, analytical and memory skills. Therefore, the local culture-based APE produced from a developmental research is so significant.

Emotional intelligence development by planting sensitivity to local culture through a game media is so significant. It will determine the next development phase of children's personality. The early age, as stated by [5], is a great time to put the basis of physical and social-emotional, self-concept, moral value, and culture development. Therefore, all early-age children's potential development will be started to make an optimum growth and development [3]. However, despite the potential benefits of the educational game, teachers do not broadly adopt it in the formal learning seating since the available games do not often fulfill the requirements of particular situations of education, and the teachers do not have advanced technological skills to create or adapt their own educational game [2]. This is a challenge for a researcherto create the educational game media to boost the emotional development needed by children to raise their awareness to their own culture.

Reaching the objective needs approach based on the children's need is to bring them closer to the cultural aspect through various culture-themed media and learning source prepared [6]. Through those strategies, the aspects developed are (1) moral values, (2) physical, (3) language, (4) cognitive aspect, (5) social-emotional aspect, and (6) art. Besides, it needs a learning management development which includes learning methodology development, learning facility and material development, including APE media. The observation carried out in the Kindergarten schools in Junrejo Sub-district of Batu City showed that in those Kindergartens, there are only $20 \%$ social culture theme based -APE used in the learning 
process, commonly APE used has a modern theme or character [7].

Local Culture Themed-Based APE which was tested to the students in Junrejo Kindergarten School has received a good response. It needs to be applied and developed to improve the children's emotional intelligence.

If the cultural elements are developed, there are some benefits will be found, such as (1) educative value (knowledge and skill), ethic (positive attitude), (2) economic value, where the wood crafter would be able to get insight about Local Culture Theme Based-APE, in another side, it can be developed for creative industry of children's toy. Students would be able to develop their emotional intelligence, including life skills, especially vocational skills [3]. Local Culture Based-APE creation will be a good tool to introduce and love the local culture, educate the children since earlier age to love and develop their imagination of Indonesia. This APE development will bring children closer to their environment so they will have a responsibility to owe and maintain it.

The research purposes were designing and developing an APE in form of the puzzle and traditional architecture stack with Indonesian local culture theme. The activity will be developed into educative, social culture, and creative industry media [8].

\section{RESEARCH METHOD}

This research is a development and creation of an art. The research phases started with (1) Reviewing research object of APE in a preschool educational institution (Kindergarten) at Batu City, East Java Province, especially in Junrejo subdistrict. (2) Designing learning media concept in the form of Local Culture Based APE. (3) Applying APE media development method through APE product design concept. (4) Validating APE development to Material Expert and Design Expert. (5) Local Culture Based APE design development results in the limited field test. (6) Revising development product result. (6) Early improving to APE product design development [9].

Formulating APE product design concept is surely by adjusting local culture characteristic and considering the principles of product design creation, including reproduction technique, educative aspect, uniqueness, practicality, which produce an APE product as the objective. In that phase, after APE is formulated, it will be continued with product design exploration phase and working technique. The exploration of shape, function, and working technique is used as a foundation to improve more excellent design [10].

Formulating APE product design development concept in written and visual (image) forms includes (a) Making alternative sketch/design image making (pre-design of APE product). (b) Choosing pre-design result in the form of APE alternative sketch image. (c) Creating work image or complete design image of creation technique guide. (d) Experiment process on selected working technique. (e) APE product experiment result. (f) Creating local culture nuance APE product design and environmentally friendly material in APE product prototype.
Next phase is doing APE concept and test of product design result development to material and media expert for Loving local culture \& Eco green-based learning embodied into product design image and prototype, also test of Kindergarten institution field as the target of development program (small field test). The next phase is fixing the limited test result of APE product design concept [11].

\section{A. Early Product/Prototype Development, Validation, and Test of Educational Game Tool (APE) Product}

The test of product result in research plays an important role. It is aiming at finding out the weakness and strength of product resulted from the research process. So, when the researcher finds weakness from development product, there can be way out to improve it. The test is a process where researcher does contact to public or communication outside the researcher's action to get assessment or response for improvement. The test of research product can be done by involving expert as the planned target. Therefore, research test can be done in several phases before test disseminated to public widely. The result of the test done gradually will be used as the foundation for development research product improvement. In this research, the test was administered through the limited test phase. The limited test was conducted to Kindergarten teacher as product user in several pre-school education institutions in Batu City and tests to preschool children education expert from the State University of Malang, also expert of children game tool product design.

Early product or prototype development is a step to formulate tentative character built from developed product. Product structure or shape is still early/prototype, has tentative character which would be improved through a sequence of test. Early product development consists of several steps carried out to get early product or prototype and ready to be tested in field, such as: (1) creating alternative sketch of various shape and function of Local Culture Based-APE and environmentally friendly material, (2) selecting the alternative images of Local Culture Based APE product design, (3) selecting the alternative design result, (4) designing Local Culture Based-APE images, completed with technical guide of work application, (5) creating Local Culture Based-APE product prototype, (6) arranging assessment/test instrument, (7) doing the validation to product design and media experts, (8) Field test, (9) revision. Development result dissemination.

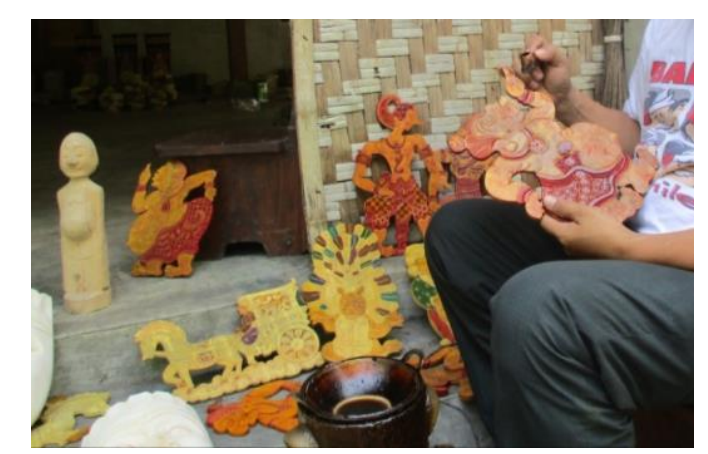

Fig. 1. Coloring Process for Educational Game Tool Using Handwritten Batik Technique. 
This learning media development is aimed to produce Local Culture Based-APE for preschool children. To make learning media effective and interesting so it would be worth to be used in learning, it needs test.

To reach test purpose, it needs accuracy in test design selection, test subject, data type, data collection instruments, and data analysis technique. In detail, test design, subject, data type, data collection instruments, and data analysis technique in ceramic interactive multimedia are:

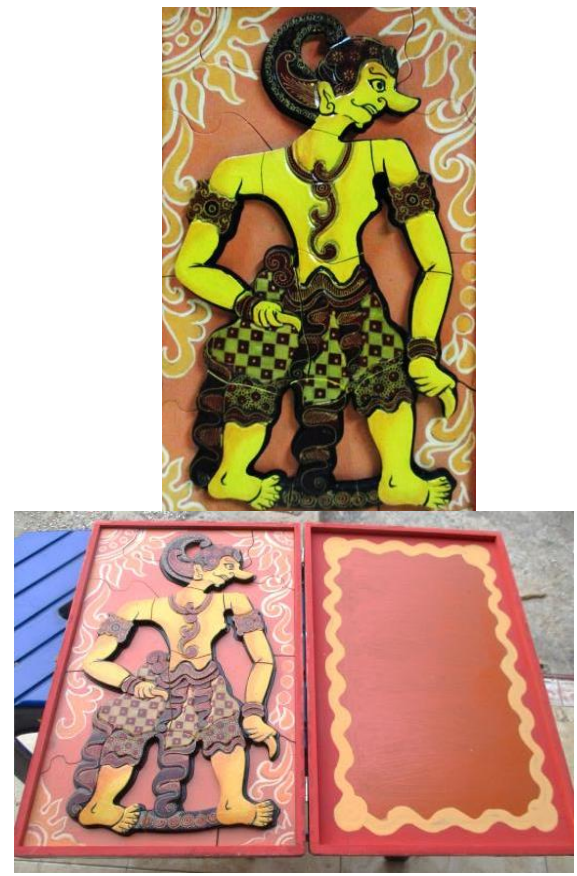

Fig. 2. Prototype of Educational Game Tool puzzle roduct with "Werkudoro" Wayang Purwo theme and its package product

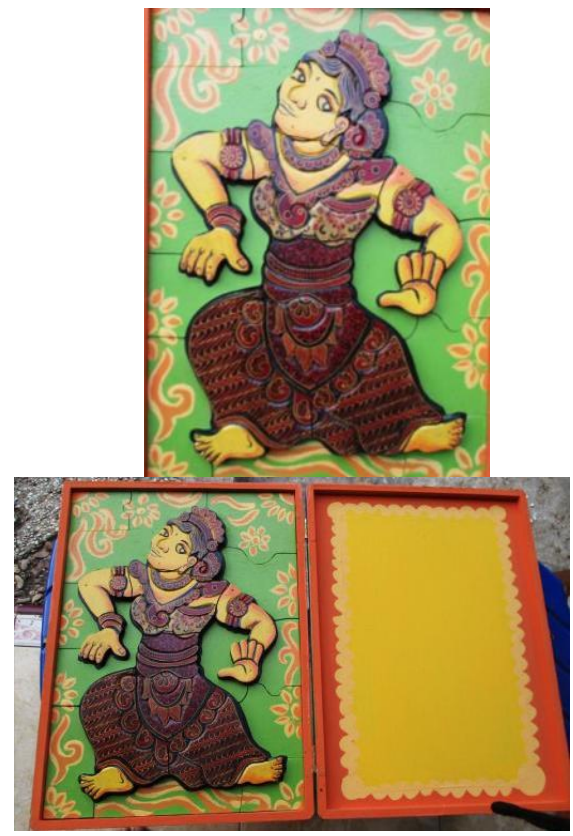

Fig. 3. Prototype of Educational Game Tool puzzle product with "Bali dance" theme and Its package product.

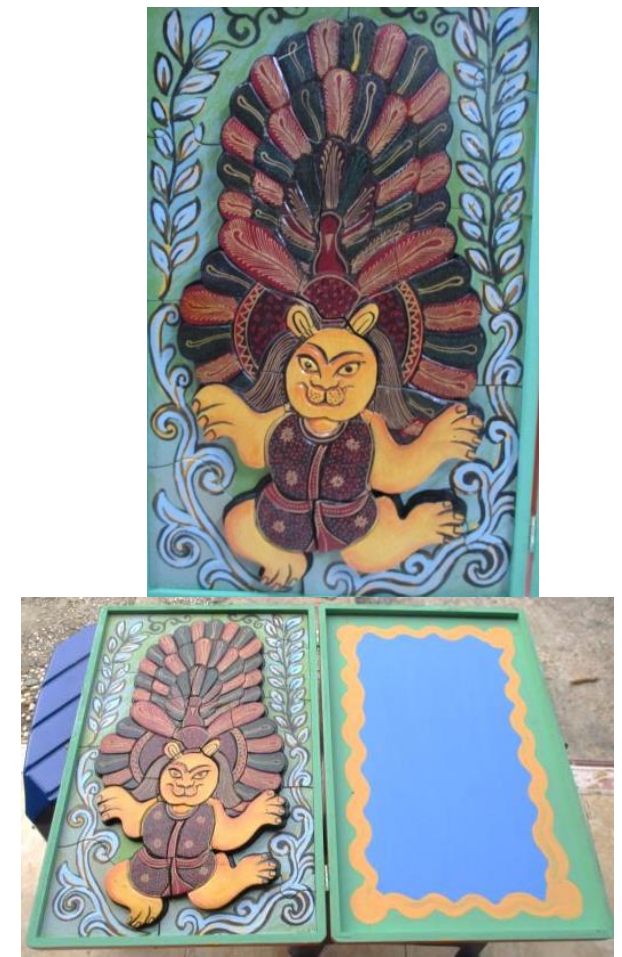

Fig. 4. Prototype of Educational Game Tool Puzzle Product with "Reog Ponorogo" theme and its package product

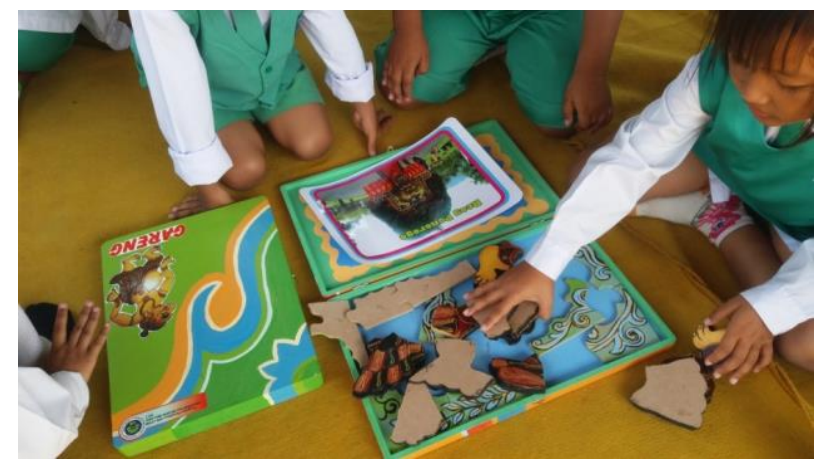

Fig. 5. Testing Educational Game Tool puzzle product with "Reog Ponorogo" theme to Kindergarten Children in Kartika Arhanud Kindergarten School of Pendem Village, Junrejo Sub-district, Batu City.

\section{B. Expert Test/Expert Evaluation}

Test was administer by two experts or validators including Local Culture Based-APE design material expert and learning media expert. Expert selection was based on product suitability and experts' skill or competence in Local Culture Based-APE product design and education media. Each expert saw and analyzed the Local Culture Based-APE product design result designed and created by developer. Then, there was a questionnaire given to the expert adjusted to their field. This questionnaire was given to get more focused data. From this expert review, it was expected to collect suggestions and advice which could be used to refine or revise early product/prototype made by developer. The validators of Loving Local Culture \& Eco green Based-APE consisted of an Expert of Craft product design field, Dr. Timbul Raharjo, the Lecture 
of Craft Art Product Design from Fine Art Department of Indonesian Art Institute (ISI) and the Expert in learning media field, Rudi Irawanto M. Ds, the Lecture of Art and Design Department, Faculty of Letters, the State University of Malang.

\section{Field Test and Improvement}

APE product design prototype which was already validated by the Expert in product design and media expert was then revised. Subsequently, it was tested in field. Field test is aiming at fixing some weaknesses or mistakes happened in the Expert test. Early field test or small group test was done to three Kindergarten institutions in Junrejo Sub-district, involving 20 Kindergarten class-B students. Subject selection use d random system, which was random selection to population as samples. Field test of the application was conducted in class through micro learning by applying or displaying APE product responded by children. In this activity, the data supporting product improvement were collected by giving questionnaire to teacher and class observation. The questionnaire was given to the teacher as a builder in the activity process [12]. Teacher observed children's attitude when they were learning and playing. Questionnaire contained some questions which should be answered by teacher based on their observation in playing while learning activity. The data collected from the questionnaire and observation were used to improve or revise the early product, so there would be found the main product, which was appropriate and ready to be used in learning. Main field test was intended to get product improvement to be a final product to use along the learning. Test to improved product was executed in larger sample since the sample should represent population whether in amount or characteristic to get the appropriateness in population context. Second phase of data collection focused on monitoring and evaluation to APE development model and its technical manual. The data collection instrument/technique, consisted of: (1) observation guide, (2) interview guide, (3) document study guide, and (4) focused discussion. Generally, the data collected in second phase research would be used as material to formulate a more comprehensive and applicative APE development model, also as foundation for recommendation formulation.

The data analysis procedure in this research was done with descriptive qualitative technique by using domain and taxonomy analysis model. Domain analysis is done whether by using folk terms, analytic terms, or mixed terms.

Taxonomy analysis, as a continuation of domain analysis, in this phase was categorizing domain based on single semantic relations. In this case, we searched parts of learning activity, relations between those parts, and comprehensive relations. From overall learning activity descriptions, the basics of domain will be given and also smaller units which form a domain. This research found Learning Model Development through Social Culture Based Educational Game Tool Usage to Improve Natural Intelligence of Playgroup Students which is ready to be implemented.

(5) There is no one better, since each person has their own advantages for different games. It minimizes ego in players'/children's personality [13].
Game development which is played by more than one person is intended to develop children's social skills, without ignoring natural and spiritual intelligence, because basically Early Childhood Education Program is considered successful if the kids obtain love to God, respect their parents, find their precious hobby, and get friends [14].

Finally, there were various toys could be bought to help Kober students' intelligence. In order to do that, the toy selection should be also suitable with the children's age and not only be useful to play, but also stimulate their intelligence comprehensively.

Playing traditional educational game is also learning development for early age-children's education. As its name, this tool has educative and traditional purposes, one of them is introducing games which has become our tradition and culture to children. To introduce the tool, it needs a tutor who already masters this traditional educational tool. In this research, the educator has creative and innovative attitudes, since in addition of creating game tool, also teaches the game to their students.

Conceptually, the general purpose of Kindergarten education is developing independence to children through game. Therefore, in its perception, children, until they reach seven years old, basically have ability to work independently. In children, there is an impulse to play, sing, and work (handcraft). In their education, Frobel dominantly used children's fantasy ability. In this case, the principle used is gradual sequence, started from the easiest one, continued with more difficult tasks. In executing Kindergarten education, a teacher should hold principle: "educating in freedom for freedom". The principle believes that children have potential to educate themselves. In its application, there is no material decided by teacher, but teacher here as a caregiver, as a children companion in their self-development spontaneously using educational game tool [15].

Game test contextually showed positive result. For example, when children were playing mekuo-kuo, there was a question whether tamarind seeds were used as game complement similar with the one used by mother to cook fish. Teacher answered that they are the same. It also happened when the children were taken outside Kober to see tamarind tree directly. They paid attention carefully, even they tried to hug the tamarind tree, and then they tried to search their fruit, peeling to see the fill and seeds. So, there would be naturalist intelligence. They would love their environment, maintain natural environment, and love to plant fruits and flowers. In this case, there will be accompanist effect, which is intentional effect that is not the early purpose of this activity.

Traditional game sourced from local culture usage is getting urgent to be reviewed further, since there are some benefits from the cognitive, psychological, or social aspects. Traditional game can also teach honest values, sportively, adversity, and togetherness.

Empirically, Cugol (Cukke Gol) game features cooperation and competition (social skills). Basketball shows cognitive skills, motoric skills and balance. Traditional game has symbolical meaning behind the movement, sayings, or tools used. Those messages are beneficial for cognitive, emotion, 
and social development of children as a preparation/learning facility to adult life. This traditional culture development and preservation should be carried out so that children in early age would be able to recognize and love their culture, so they would not be crashed by modern people age and dynamics. For children, game is something fun and exciting, since those game satisfied environmental exploration preparing various variance involving children's senses.

There are two rules to begin a game, which are: (1) both side deals without any pressure by opponents or outside party, (2) through lottery using rock or wood/board, then they started the game. In fact, there is almost no. protest, violation of rules, or feeling offended among children who are playing [16].

Rapid development of electronic game made traditional game position is endangered and almost unknown. From that view, this research results become more urgent, along with [17] view who stated it needs effort from various parties to review and preserve their existence through re-learning in current generation and modification process adjusted with current conditions.

National insight planting to early age-children through APE is expected can prepare them as humans who have identity in their local people, also global vision to build the world together. Education is expected to build such people.

This research asked educators, parents, and society to provide educational game tool which would be able to build children characters since the early age, with Indonesian local culture toy. Although in other side, children could not be taken too far from import games. We can select the correct tool by paying attention to children's age development and choosing toy which does not bring damage to the nation culture. According to [15], many imported toys made us susceptible to culture colonialism from those game tools.

Indonesian elements are expected to be integrated in APE made by educators, home industries, or manufactures. Traditional houses can be produced in doll house sizes. Its details can be similar to traditional home, but its accessories do not have to be in details. Through traditional house for dolls, children would be introduced to Indonesian traditional houses. The materials do not have to be made from wood; carton is already available, where educators make simple traditional houses for children to play. By this traditional house, children can do role-play, sewing, printing, calculating, and pattern playing. Through batik or songket, we could do various games and made APE to introduce Indonesian traditional fabric, e.g.: playing puzzle, playing pattern, classification, batik making, and drawing, calculating similar and not similar number, fabric length measurement, role-playing, jumping and walking while still using the fabric.

Along this time, educator and Kober and common Early Childhood Education Program placed APE as the main obstacles in developing Kober. They understand that good APE can only be achieved by purchasing from the other countries. Teacher's creativity in developing learning material of traditional educative game tool is the accompanist effect which describes a long term effect reached from an education program [18].
Another accompanist effect which can be done is parents and students involvement to create learning material in the form of game tool, such as: tinggo kasu, tinggo ulo, patolele, mehule; economical effect is also the accompanist effect. It changes educator's and parents' thought which along this time understands that game is supposed to be learned in school or Kober should import the game bought with expensive price. Educator and parents slowly will recognize the needs of creativity in developing learning material for children. It will also create further accompanist effect; when children grow up, they will produce creative and innovative thoughts to explore their natural resource in productive and economic ways, also pay attention to nature preservation, since they have learned to love the natural environment (natural intelligence) since the early age.

Instructional phase is learning result that is appropriate with purpose, while accompanist effect is another learning result produced by learning process [19].

Both effects were found in this research sequence, which also showed that this research process has run well since in addition of reaching formulated purpose, it also achieved double benefits, in the form of accompanist effect which can be categorized as the indicator of research success. To see further the effectiveness in game learning implementation to Kober children, it needs continuous program in the form of dissemination through Community Service, so that learning effectiveness using this social culture based educational game tool can be measured more effectively since it can be transferred or adopted by wider subjects [20].

These findings give people's awareness of their environment potentials, whether natural environment or social culture environment. This potential can be better if it is supported by creative people, who can be born from such development program, whether from educator, students, or communities. Educative and psychological effects from this development are a start to review its effects in preserving and developing culture and nature, which at the end could improve Regional Income through cultural tourism package and natural tourism, also small industries/crafts.

\section{CONCLUSION}

In educative way, developed tool is easier to find and could improve children's natural intelligence, also improve education workforce creativity. It has proven that children love to naturally play this tool and more easily understand the raw material and game complement which come from environment around the students, including the other benefits from the raw material and game complement. Educators, in addition of developing two social culture based traditional game, also has Kober educator who also successfully developed learning material by using material from Kober nature potentials.

The response from public figure, parents, and educators to this traditional educational game tool is they said that this game could return the children's childhood, and they love it. They play with it and race between them. Almost forgotten culture returns and it could compete with the other culture, the imported game tool, while the later one is difficult to develop children's creativity as the effect of instructional or 
accompanist effect. Culture development and natural environment potentials will enable to easily reach the goal and give the chance to more accompanist effect and more qualified culture products.

There are 12 types of game tool that has been developed economically, its production is easy and cheap compared to non-traditional one. It could be developed to sell in the market as well, which would give economical value for teach groups that develop it. The eight game tools have been developed by Kober mostly made by educator and parents, except board for mekuo-kuo/congklak game tool, since it needs carpentry tool, while all Kober educators are female. Even so, the other tools such as stone and seeds are collected by educators and their students.

The teachers of Early Childhood Education Program need more training to develop game tool, whether from traditional culture or what apply new motive suitable with the nation culture and personality. We need the formulation of Early Childhood Education Program curriculum which pays attention to social culture potential and nature around the Early Childhood Education Program.

The students of Early Childhood Education Program students need AMET game race, so they could develop their affection to the nation culture. The educators of Early Childhood Education Program educators need APET development race, so they could be more creative in teaching material procurement, whether in game quantity or quality. Rapid development of electronic game makes traditional game unknown. It needs real effort from Education and Culture Department, and Tourism Department, public figures, teachers, and parents to do more review and conserve it via re-learning to current generation through modification adjusted with environment conditions.

\section{REFERENCE}

[1] S. Malik and A. Agarwal, "Use of multimedia as a new educational technology tool-A study," Int. J. Inf. Educ. Technol., vol. 2, no. 5, p. 468, 2012.

[2] J. Melero and D. Hernandez-Leo, "A Model for the Design of Puzzlebased Games Including Virtual and Physical Objects," Educ. Technol. Soc., vol. 17, no. 3, pp. 192-207, 2014.

[3] A. Anwar, Pendidikan anak usia dini. Bandung: Alfabeta, 2004.

[4] W. Orawiwatnakul, "Crossword Puzzles as a Learning Tool for Vocabulary Development," Electron. J. Res. Educ. Psychol., vol. 11, no. 2, pp. 413-428, 2013.

[5] L. Hanurani, "Beberapa Cara Mengidentifikasi Sumber Belajar dan Kebutuhan Belajar dalam Masyarakat," Gita Setrai, vol. 2, no. 2003, 2003.

[6] Direktorat Padu, "Acuan Menu Pembelajaran pada Kelompok Bermain," Jakarta, 2002.

[7] A. Anwar, "Pengembangan Model Pembelajaran Melalui Pemanfaatan Alat Permainan Edukatif Berbasis Sosial Budaya untuk Meningkatkan Kecerdasan Naturalis pada Anak Didik Kelompok Bermain,” Kendari, 2009.

[8] I. Surviani, Point Penting dalam Menghias Jiwa \& Perilaku Anak. Bandung: Pustaka Ulumuddin, 2009.

[9] U. Suharsaputra, Metode Penelitian Kuantitatif, Kualitatif, dan Tindakan. Bandung: Refika Aditama, 2012.

[10] D. Dharsono and S. Kartika, Kreasi Artistik: Perjumpaan Tradisi Modern dalam Paradigma Kekarya Seni. Surakarta: Citra Sain, 2016.
[11] D. Campbell, Mengembangkan Kreativitas. Yogyakarta: Kanisius, 1986.

[12] S. Sardjiyo and P. Pannen, "Pembelajaran Berbasis Budaya: Model Inovasi Pembelajaran dan Implementasi Kurikulum Berbasis Kompetensi," J. Pendidik., vol. 6, no. 2, pp. 83-98, 2005.

[13] A. Ahira, "Permainan-permainan tradisional," 2010. [Online]. Available: http://webcache.googleusercontent.com/search?q= cache:IBgT6G9pzXIJ:www.anneahira.com/permainan/permainantradisional.htm+ permainan+tradisional\&cd=1\&hl=id\&ct=clnk\&gl=id. 26 November 2010. [Accessed: 28-Aug-2017].

[14] F. Jalal, "Pendidikan, Input Tumbuh Kembang Anak," www.pikiranrakyat.com, 2007. .

[15] R. Rostrianawahti, "No Title,"www.nasimaedu.com, 2009. [Online]. Available: http://www.nasimaedu.com/artikel/index.php?do=15. Akses, 28 Juli 2009. [Accessed: 28-Jul-2009].

[16] D. Wardani, "Potret Permainan Tradisional Indonesia," 2009.

[17] N. Nurchasanah, "Pengembangan Bahan Ajar Untuk Meningkatkan Perilaku Anak Prasekolah Melalui Kreativitas Bahasa," Bhs. Seni Bahasa, sastra, Seni, dan Pengajarannya, vol. 41, no. 1, p. 119, 2013.

[18] I. E. Wulandari, "Pembelajaran yang Menumbuhkan Kepedulian: Studi Kualitatif Fenomenologis di Sekolah Dasar Gunung Brintik, Semarang, Jawa Tengah.," Malang State University, 2009.

[19] S. Sudaryono, "Klinik pendidikan model pembelajaran yang efektif," www.jambiekspres.co.id, $2009 . \quad$ [Online]. Available: http://74.125.153.132/search?q=cache:iHCNvAG9ClkJ:www.j ambiekspres.co.id/index.php/guruku/3090-klinik-pendidikan-modelpembelajaran-yang-

efektif.html+dampak+pengiring \&cd=9\&hl=id\&ct=clnk\&gl=id\&clientfir efox-a. . [Accessed: 30-Oct-2009].

[20] I. Musbikin, Mendidik Anak Kreatif Ala Einstein. Yogyakarta: Pustaka Pelajar, 2006. 